\title{
The manifestations of acid attacks (vitriolage or vitriolism)
}

\section{Roger W. Byard ${ }^{1}$ (I)}

Accepted: 21 February 2020 / Published online: 25 March 2020

(C) Springer Science+Business Media, LLC, part of Springer Nature 2020
"Acid attacks" refer to physical assaults where an acid or corrosive material is thrown over another individual with the intention to "maim, disfigure, torture or kill" [1]. As can be seen in the review by Kaur and Kumar in this issue [2] it can be a particularly devastating form of violence, as it is often associated with severe, permanent, disfiguring and incapacitating injuries with loss of tissue and organ function. Also known as vitriolism or vitriolage, the incidence varies greatly among different cultural and ethnic groups, as do the motivations behind such events.

The largest number of cases has occurred in Bangladesh with 3000 reported since 1999, although rates have been decreasing, with 116 cases in 2009 compared to 367 in 2002 [3]. As noted by Kaur and Kumar victims are most often young women who have refused marriage proposals or sexual advances [2]. It has also been reported following property or dowry disputes, or as part of more generalized domestic violence [4]. Similar motivations lie behind acid attacks in India although disturbingly the numbers in that country appear to be increasing. This may be particularly so given the suggestion that under-reporting may occur, especially with fatal cases in rural areas [5-7]. In Pakistan annual numbers have increased from 65 in 2010 to 150 in 2011 [8].

Acid attacks may also be used by criminal gangs as a form of punishment or intimidation. In the United Kingdom (UK) there has been a dramatic rise in cases of acid attacks with numbers increasing from 228 in 2012 to 601 in 2016 [9]. Most of the attacks occurred in London and often involved street gangs using "face melters", with predominantly male perpetrators and victims [10]. Pouring acid into the eyes of 33 prisoners between 1979 to 1980 in Bhagalpur, India, was

Roger W. Byard

roger.byard@sa.gov.au

1 Adelaide School of Medicine, The University of Adelaide, Level 2 Helen Mayo North Building, Frome Road,

Adelaide, SA 5005, Australia allegedly undertaken by police to intimidate suspects [11] Reports of acid attacks have come from many countries including Jamaica, Iran, Taiwan, Colombia, Nepal, Uganda, Cambodia, United States, China, South Africa, Saudi Arabia, and Nigeria, where they accounted for $5.7 \%$ of burn patients in one study [9, 12-16].

Although sulfuric and nitric acid are usually employed, sometimes strong alkaline solutions such as sodium hydroxide may be substituted, particularly if access to acids has been restricted [17]. The effects of corrosive burning vary depending on the part of the body that has been targeted, but as many attacks involve the face and head the results are often limited to this area. Severe attacks may cause deaths due to the immediate effect of the burns, or at a later time from sepsis or multi-organ failure. However, as the head is often targeted, victims usually have less than $20 \%$ of the total body surface burned and so survival is usual, with $8.1 \%$ mortality in one Iranian study [12]. A British study reported that only $2 \%$ of cases had life threatening injuries [18]. Suicide due to the severely damaging psychological and emotional effects of the resultant physical deformities may occur [8]. Survivors often shun social interaction and live as outcasts [19] and it has been estimated in a study of survivors in Bangladesh that more than a third suffered anxiety, depression and posttraumatic stress [20]. Steps have been taken in India to try to restrict the sale of acids legislatively and to make acid attacks a non-bailable offence [21], however the effectiveness of this has been questioned $[2,22]$.

In survivors there may be severe deformation of the nose with collapse of the bridge and stenosis of the nostrils, destruction of ear cartilage and soft tissues with deafness, loss of eyelids and/or eyes with blindness, loss of lips with stenosis of the mouth causing difficulties with eating, drinking and speaking, dense scarring of the neck limiting head and neck movement and scarring of the shoulders limiting arm movement as was seen in the Kaur and Kumar review [2]. Inhalation of vapors may also cause damage to the upper aerodigestive tract, esophagus and lungs. Hair may have been lost and deep burns may even have caused damage to skull bones [23]. 
Caustic substances may sometimes also be ingested in suicide attempts and again the incidence displays marked geographic/cultural variation. For example, although rare in Australia [24], the incidence is much higher in India where sulfuric and hydrochloric acids are used [25], or in Surinam where glacial acetic acid is favored [26]. Deaths result from caustic burns with hemorrhage or perforation of the upper gastrointestinal tract, or from subsequent multiorgan failure or sepsis $[24,27]$. These cases are, however, clearly different to corrosive assaults.

Acid attack represents a particularly heinous form of assault that has been reported in many countries. In Bangladesh and India it is a gender-based crime associated with perceived relationship, marriage or dowry issues. This contrasts with the United Kingdom where males are the usual victims with attacks resulting from gang-based activities. Whatever the local sociodemographic features, acid attacks are designed to seriously hurt and maim victims, rather than killing them, thus causing significant and protracted physical and emotion suffering. The increase in numbers of cases in some communities is of considerable concern, although legislative changes and campaigns such as "Stop Sale Acid" [2] are certainly very positive initiatives in this area.

\section{References}

1. Lewis CJ, Hodgkinson EL, Allison KP. Corrosive attacks in the UK - psychological perpsectives and decontamination strategies. Burns. 2019. https://doi.org/10.1016/j.burns.2019.06.003.

2. Kaur N, Kumar A. Vitriolage (vitriolism) - a medico-socio-legal review. Forensic Sci Med Pathol. 2020. https://doi.org/10.1007/ s12024-020-00230-7.

3. Combating acid violence in Bangladesh, India, and Cambodia. Avon Global Center for Women and Justice at Cornell Law School, Committee on International Human Rights of the New York City bar Association, Cornell Law School international Human Rights Clinic, and the Virtue Foundation. 2011. https:// www2.ohchr.org/english/bodies/cedaw/docs/cedaw_crc contributions/AvonGlobalCenterforWomenandJustice.pdf. Accessed 24 Dec 2019.

4. Baseline Report: Violence Against Women in Bangladesh. International Women's rights action watch Asia Pacific, Kuala Lumpur, Malaysia. https://web.archive.org/web/20130922173913/ http://www.iwraw-ap.org/aboutus/pdf/FPvaw.pdf. Accessed 24 Dec 2019.

5. Dhar S. Acid attacks against women on the rise in India. 2017. https:/www.usatoday.com/story/news/world/2017/07/27/acidattacks-women-india-survivors-fight-back/486007001/. Accessed 24 Dec 2019.

6. Why acid attacks are on the rise in India. https://www.dw.com/en/ why-acid-attacks-are-on-the-rise-in-india/a-19313750. Accessed 24 Dec 2019.

7. Ahmad NA. Weak laws against acid attacks on women: an Indian perspective. Med Leg J. 2012;80:110-20.

8. Walsh D. Years after acid horror, suicide stirs Pakistan. https:// www.nytimes.com/2012/04/10/world/asia/hope-in-pakistan-forcurbing-acid-attacks.html. Accessed 24 Dec 2019.
9. A worldwide problem. Acid Survivors Trust International. http:// www.asti.org.uk/a-worldwide-problem.html. Accessed 24 Dec 2019.

10. Dewan A. 2017 Was the worst year for acid attacks in London. https://edition.cnn.com/2018/01/26/europe/london-acid-attacks2017-intl/index.html. Accessed 24 Dec 2019.

11. Muzaffar M. These brutal blindings shook a nation . . . and they're still happening. https://www.ozy.com/true-and-stories/these-brutalblindings-shook-a-nation-and-theyre-still-happening/95240/. Accessed 24 Dec 2019.

12. Vaghardoost R, Kazemzadeh J, Dahmardehei M, et al. Epidemiology of acid-burns in a major referral hospital in Tehran. Iran World J Plast Surg. 2017;6:170-5.

13. Rasouli HR, Ebrahimi A, Motamedi MHK. Raising awareness against acid attacks. Lancet. 2015;385:772-3.

14. Mannan A, Ghani S, Clarke A, Butler PEM. Cases of chemical assault worldwide: a literature review. Burns. 2007;33:149-54.

15. Breaking the silence addressing acid attacks in Cambodia. Cambodian Acid Survivors Charity, May 2010. https://web.archive.org/web/ 20131219010314/http://www.cambodianacidsurvivorscharity.org/ docs/breaking_the_silence.pdf. Accessed 24 Dec 2019.

16. Olaitan PB, Jiburum BC. Chemical injuries from assaults: an increasing trend in a developing country. Ind J Plast Surg. 2008;41: 20-3.

17. Welsh J. "It was like burning in hell" A comparative exploration of acid attacks. Center for Global Initiatives, Carolina Papers. Master of Arts thesis, University of North Carolina; 2009.

18. Nagarajan M, Mohamed S, Asmar O, Stubbington Y, George S, Shokrollahi K. Data from national media reports of 'acid attacks' in England: a new piece in the jigsaw. Burns. 2019; doi: org/https:// doi.org/10.1016/j.burns.2019.10.027.

19. Heanue S. Indian acid attacks are on the rise, and the women who survive them are forced to live as outcasts. https://www.abc.net.au/ news/2019-08-24/indian-acid-victims-want-to-break-down-socialstigma/11428952. Accessed 24 Dec 2019.

20. Mannan A, Ghani S, Clarke A, White P, Salmanta S, Butler PEM. Psychosocial outcomes derived from an acid burned population in Bangladesh, and comparison with Western norms. Burns. 2005;32: 235-41.

21. Kay M. Indian court restricts the sale of acid to try to curb attacks on women. BMJ. 2013;347:f4762.

22. Singh M, Kumar V, Rupani R, et al. Acid attack on women: a new face of gender-based violence in India. Ind J Burns. 2018;26:83-6.

23. Acid Violence in Uganda: A Situational Analysis. Acid Survivors Foundation Uganda. November 2011. pp. 1-21. https://web. archive.org/web/20130617010909/http://www.acidviolence.org/ uploads/files/Uganda_ASFU_Situational_Analysis_Report_ FINAL_Nov2011_1.pdf. Accessed 24 Dec 2019.

24. Byard RW. Caustic ingestion - a forensic overview. J Forensic Sci. 2015;60:812-5.

25. Arévalo-Silva C, Eliashar R, Wohlgelernter J, Elidan J, Gross M. Ingestion of caustic substances: a 15-year experience. Laryngoscope. 2006;116:1422-6.

26. Poley JW, Steyerberg EW, Kuipers EJ, Dees J, Hartmans R, Tilanus HW, et al. Ingestion of acid and alkaline agents: outcome and prognostic value of early upper endoscopy. Gastrointest Endosc. 2004;60:372-7.

27. Ertekin C, Alimoglu O, Akyildiz H, Guloglu R, Taviloglu K. The results of caustic ingestions. Hepatogastroenterology. 2004;51: $1397-400$.

Publisher's note Springer Nature remains neutral with regard to jurisdictional claims in published maps and institutional affiliations. 